\title{
Geomorphological features of active tectonics and ongoing seismicity of northeastern Kumaun Himalaya, Uttarakhand, India
}

\author{
Vivekanand PathaK ${ }^{1, *}$, Charu C Pant ${ }^{1}$ and Gopal Singh Darmwal ${ }^{2}$ \\ ${ }^{1}$ Centre of Advanced Study in Geology, Kumaun University, Nainital 263 002, India. \\ ${ }^{2}$ Geological Survey of India, Jaipur 302 004, India. \\ *Corresponding author. e-mail: vpathak1908@gmail.com
}

The northeastern part of Kumaun Lesser Himalaya, Uttarakhand, India, lying between the rupture zones of 1905, Kangra and 1934, Bihar-Nepal earthquakes and known as 'central seismic gap' is a segment of an active fault known to produce significant earthquakes and has not slipped in an unusually long time when compared to other segments. The studied section forms a part of this seismic gap and is seismically an active segment of the Himalayan arc, as compared to the remaining part of the Kumaun Lesser Himalaya and it is evident by active geomorphological features and seismicity data. The geomorphological features of various river valley transects suggest that the region had a history of tectonic rejuvenation which is testified by the deposition of various levels of terraces and their relative uplift, shifting and ponding of river channels, uplifted potholes, triangular facets on fault planes, fault scarps, etc. Further, the seismic data of five-station digital telemetered seismic network along with two stand alone systems show the distribution of earthquakes in or along the analyzed fault transects. It is observed that the microseismic earthquakes (magnitude 1.0-3.0) frequently occur in the region and hypocenters of these earthquakes are confined to shallow depths (10-20 km), with low stress drop values (1.0-10 bar) and higher peak ground velocity (PGV). The cluster of events is observed in the region, sandwiched between the Berinag Thrust (BT) in south and Main Central Thrust (MCT) in north. The occurrences of shallow focus earthquakes and the surface deformational features in the different river valley transect indicates that the region is undergoing neotectonic rejuvenation. In absence of chronology of the deposits it is difficult to relate it with extant seismicity, but from the geomorphic and seismic observations it may be concluded that the region is still tectonically active. The information would be very important in identifying the areas of hazard prone and also planning and designing of the socio-economic projects.

\section{Introduction}

The Himalaya is the most prominent and active orogeny of the world. The seismotectonic aspects of this structure are still poorly known, as the accurate rate of crustal shortening across the range and the distribution of this deformation over the orogenic domain also varies in different provinces (Sridevi 2004). The topography, geologic structure and earthquakes of the Himalaya and surrounding regions are a result of northward movement of Indian landmass and its collision with Eurasian Plate. Recent studies on plate motion and Global Positioning System (GPS) measurements show that about $50 \%$ of the total 50$60 \mathrm{~mm} / \mathrm{yr}$ of convergence is taken up by thrust motion along the Himalayan arc, while the remaining is taken up farther north by a combination of

Keywords. Northeastern Kumaun; central seismic gap; geomorphology; seismicity; telemetered seismic network. 
thrusting, crustal extension and strike-slip motion within the Eurasian Plate (Avouac and Tapponnier 1993; Bilham et al. 1997, 1998; England and Molnar 1997; Larson et al. 1999; Wesnousky et al. 1999; Senthil et al. 2001; Banerjee and Burgmann 2002; Parkash et al. 2011). The northward convergence of India resulted in crustal shortening of the northern margin of the Indian continent and convergence accommodated by three south-verging thrust faults that strike the length of Himalayan arc. The northern-most thrust is the Main Central Thrust (MCT) which demarcates the lower boundary of the Great Himalaya and separates the massive, north dipping pile of metamorphic rocks that constitute the Central Crystalline Zone of the Greater Himalaya from the Lesser Himalaya. The Main Boundary Thrust (MBT), separates the Lesser Himalaya (a thick pile of highly folded upper Precambrian sedimentary units with a few outcrops of crystalline rocks) from the Tertiary Siwalik Supergroup in the south. The MBT is expressed in the bedrock along the arc, and is locally observed to displace Quaternary deposits (Nakata 1989; Goswami and Pant 2007). The southernmost thrust is the Himalayan Frontal Fault (HFF) that separates the youthful Siwalik Hills made up of late Tertiary to early Quaternary molasses from the Indo-Gangetic plain in the extreme south. All of the three principal thrusts show progressively younger ages and shallower depths from north-south, indicating southward migration of the main deformation front (Thakur 2004). Due to the northward push of the Indian Plate into the Eurasian Plate, the entire Himalayan mountain system is under stress and rocked by the several large-to-great magnitude earthquakes. Four earthquakes of magnitude $\geq 8$ have been experienced at the foothills of Himalaya, namely the 1897 (Shillong earthquake, Ms 8.7), 1905 (Kangra earthquake, Ms 8.6), 1934 (Bihar-Nepal border earthquake, Ms 8.4), and 1950 (Assam earthquake, Ms 8.7). Hence, the Uttarakhand Himalaya and part of western Nepal, lying between the rupture zones of 1905 (Kangra) and 1934 (Bihar-Nepal) are identified as the central seismic gap (Khattri and Tyagi 1983) region. In the present investigation, an attempt has been made to understand the neotectonics and seismotectonic activities in the vicinity of the MCT, along Kali, Dhauliganga, Gori Ganga and Ramganga east river valleys, in Kumaun Himalaya which also forms a part of the central seismic gap. The study area is enclosed between the latitudes $29^{\circ} 49^{\prime}-30^{\circ} 20^{\prime} \mathrm{N}$ and longitudes $80^{\circ}-80^{\circ} 36^{\prime} \mathrm{E}$.

\section{Geological and tectonic settings}

The area covers the major part of inner Lesser Himalaya and a portion of Greater Himalaya in northeastern Kumaun. The area is bounded by two major thrusts namely Main Central Thrust (MCT) in the north and North Almora Thrust (NAT) in the south. The Main Central Thrust is moderately north dipping crustal shear zone, which has formed as a result of southward emplacement of a part of deeply rooted crust over the less metamorphosed sedimentary units of the inner Lesser Himalaya (Valdiya 1980; Bhattacharya and Weber 2004). The NAT is also a north-dipping thrust that demarcates the southernmost limit of the study area. The present study area comprises of two major geotectonic domains each characterized by distinct lithological composition, structural pattern and magmatic element which have been recognized in the northeastern Kumaun Himalaya between Ramganga and Kali rivers. These tectonic domains are central crystalline in the north and sedimentary terrain in south.

The sedimentary terrain of inner Lesser Himalaya constitutes the autochthonous unit of Precambrian sediments. It is exposed in the windows and involved in complex tight folding. The sedimentary unit shows little or no metamorphism as some sedimentary structures are preserved in these rocks (Valdiya 1980). The sedimentary sequence is represented by Damtha and Tejam groups. The 'Central Crystalline' or 'Central Crystalline Zone' which makes up a major part of Great Himalaya is a distinct tectonic unit, thrusted over the sedimentary rocks of Lesser Himalaya along the MCT. Thus, the central crystalline (hanging wall) and sedimentary rock of the Lesser Himalaya (footwall) have been affected by strong ductile deformation as a consequence of the thrusting along the MCT (Bhattacharya and Weber 2004) and compression of the whole of the Himalayan province resulted in folding of nappes as well as their root at the foot of the Great Himalaya. This is seen in the Kali-Gori valleys in the east. The Central Crystalline Zone in the Kumaun Himalaya comprises of two major thrust bound lithotectonic units characterized by two distinct suites of metamorphics showing distinct metamorphic characters, petrological composition and structural patterns (Valdiya 1980). The lower one designated as the Munsiari Formation, consists of Middle Proterozoic granites and its mylonitized variants. The upper unit called the Vaikrita Group (figure 1a) comprises of medium to high grade metamorphic and intrusive porphyritic gneissic granites. The tectonic boundary which separates the two aforesaid units has been called as the Vaikrita Thrust (Valdiya 1979). The generalized tectonic map of the area is shown in figure $1(\mathrm{~b})$. 


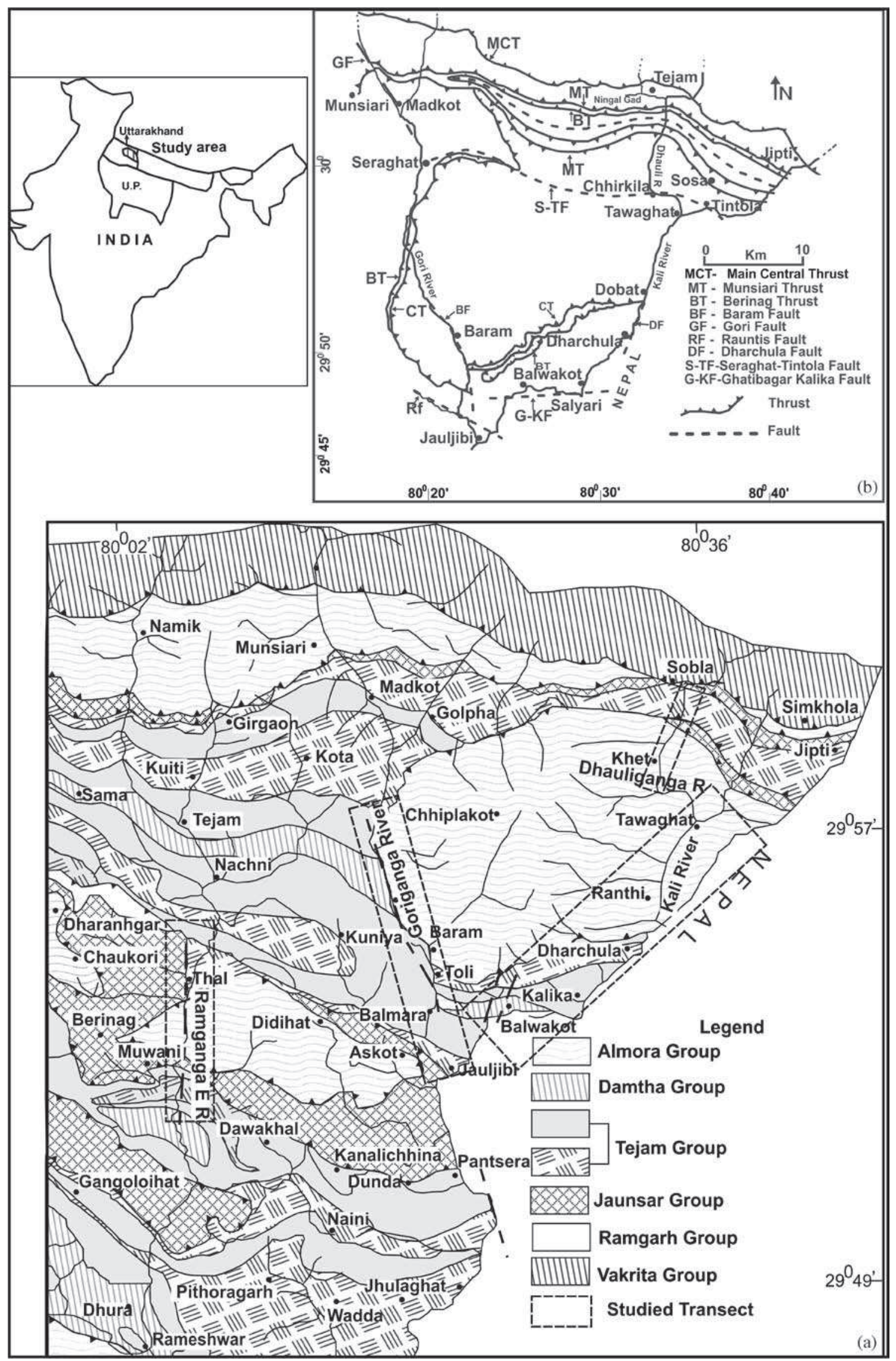

Figure 1. (a) General geological map (after Valdiya 1980) of the region and (b) structural map of the area (after Paul 1985), respectively. 


\section{Methodology}

River valleys are very sensitive indicators of neotectonic activities, therefore some of the biggest rivers, i.e., Kali, Dhauliganga (east), Gori Ganga and Ramganga (east) of the Kumaun were considered in this investigation. On the basis of the detailed study of recorded geomorphic features, tectonically active faults/lineaments were identified and an attempt was made to evaluate the effect of tectonic activity and geomorphic development of the area.

The seismic data of the region were acquired from the five station short period (L4-3D) digital radio frequency network along with two broadband stand alone systems. The network/system acquires seismic data in continuous mode (100 samples/seconds). The transmitted data is stored in data acquisition computer at Central Recording Station (CRS). The earthquake data is extracted and filtered during the analysis. The primary $(\mathrm{P})$ and secondary $(\mathrm{S})$ waves were marked on the digital seismogram. The event recorded at least by three stations, is considered in the study. The Pwave velocity model developed by Khattri et al. (1989), is used in the present work. It gives the lowest error for hypocenteral parameters while using HYPO-71 computer programme developed by Lee and Lahr (1975). The source parameters of the events were computed from the spectral analysis of $\mathrm{P}$-waves in the vertical component of the displacement waves by using Brune's model and the following formula (e.g., Brune 1970; Sharma and Wason 1994).

$$
\begin{aligned}
& M o=4 \pi \rho v^{3} D A o / R, \\
& r=2.34 v / 2 \pi f c, \\
& \Delta \sigma=7 M o / 16 r^{3},
\end{aligned}
$$

where $M o$ is the average seismic moment and computed from different recording stations for the event, $\rho$ is the density at the source, $v$ is $\mathrm{P}$-wave velocity at the source, $r$ is the source radius, $f c$ is corner frequency, $\Delta \sigma$ is stress drop, $D$ is epicentral distance, $A o$ is low frequency spectral level of $\mathrm{P}$-wave, and $R$ denotes radiation pattern.

\section{Geomorphic analysis of selected rivers}

To understand the tectonic rejuvenations of the area, major river valleys/systems were selected for the documentation and delineation of the geomorphologic features. Rivers are largely influenced by active tectonics, and the fluvial systems are sensitive to both faulting and regional surface deformation (Keller and Pinter 1996). The valley incision can result from crustal uplift and climatic changes. Although climate change alone cannot provide a mechanism for progressive incision (Bull and Knuepfer 1987; Bull 1991; Maddy et al. 2000). Therefore, the present investigation focusses on different features of active tectonics, viz., unpaired terraces, paleochannels, springs, waterfalls, fault facets, fault scarps, etc., along the transect. The spatial distribution pattern of such features has been used as a reliable tool of documenting the active tectonics of the Lesser Himalayan terrain (e.g., Valdiya 1986, 2001; Goswami and Pant 2008; Pathak et al. 2013). Details of these are shown in figures $(2,5,7)$, which were delineated on the basis of the observed features. Description of these features in various river valleys are described below.

\subsection{Geomorphic indicator of neotectonic activities along Kali and Dhauliganga river valleys}

Kali river is the largest river in Kumaun both in terms of volume of water as well as extent of the catchment area. Kali, like other Himalayan rivers, is a snowfed river and has a great potential for irrigation and hydroelectric power generation. It marks the entire eastern boundary of Kumaun, separating it from Nepal, all along its length. In its upper reaches, Kali is a roaring stream flowing in gorges with rare preservation of terraces, while further downstream it usually has a wide valley, covered with huge boulders, gravels and sand, with deposition of paired and unpaired terraces commonly related to the different phases of rejuvenation along major active faults (Nakata 1975; Valdiya 1986; Sah and Virdi 1997).

The occurrences of terraces at different levels can indicate past evidence of channel shift and continuous uplift of the terrain. Several geomorphic signatures of neotectonic activities are seen during field investigation in the Kali valley from Tawaghat to Titari village (figure 2). On the way from Rela Gad to Tawaghat, Kali river flows through a quiet, narrow valley in its upper courses. The river flows in a deep gorge characterized by high gradient, very turbulent flow exposing bedrocks. There are number of waterfalls and no terrace development except, some strath terraces locally. The deep cut, $\mathrm{V}$-shaped or convex slopes of gorges and abrupt narrowing of Kali upstream of crossing the faults, reflects neotectonic activity in this region.

Three distinct levels of terraces are exposed at Dharchula (Indian side), while four levels of welldeveloped terraces are seen in Darchula (Nepal side) (figure 3a). At Dharchula $\mathrm{T} 1$ is $5 \mathrm{~m}$ from the present river level, T2 occurs at a height of $8 \mathrm{~m}$ from $\mathrm{T} 1$ surface and $\mathrm{T} 3$ is $20 \mathrm{~m}$ from T2 surface. While in Darchula, T1 is $5 \mathrm{~m}$ from the present river 


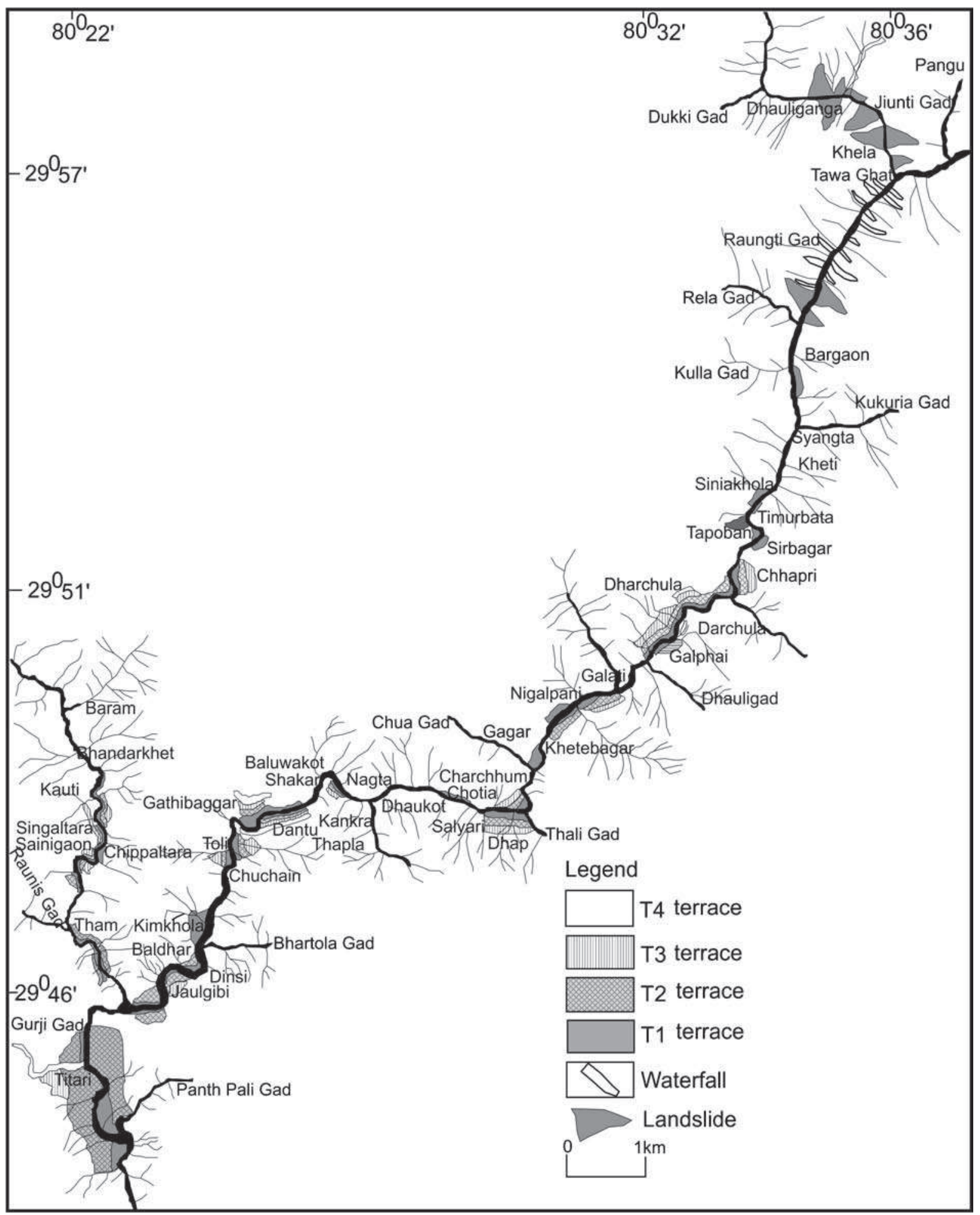

Figure 2. Geomorphological map of Kali and Dhauliganga river valleys.

level, T2 being $8 \mathrm{~m}$ from T3 surface, T3 occurs at $7 \mathrm{~m}$ height from T2 surface and T4 is $20 \mathrm{~m}$ from T3 surface. This is related to tectonic activity along NE-SW trending Dharchula Fault along Kali river valley near Dharchula. This has caused differential uplift of the terraces and its existence is also evidenced by the presence of triangular facets and scarps on the Nepal side and landslides all along the valley prove its active nature.

Four distinct levels of terraces are developed at Dantu (Nepal) and Gathibaggar (India). At Dantu village, T1 occurs $4 \mathrm{~m}$ from the present river level, T2 occurs $8 \mathrm{~m}$ above from T1, T3 being exposed at $15 \mathrm{~m}$ from $\mathrm{T} 2$ and $\mathrm{T} 4$ (Urain gaon) occurs at a height 


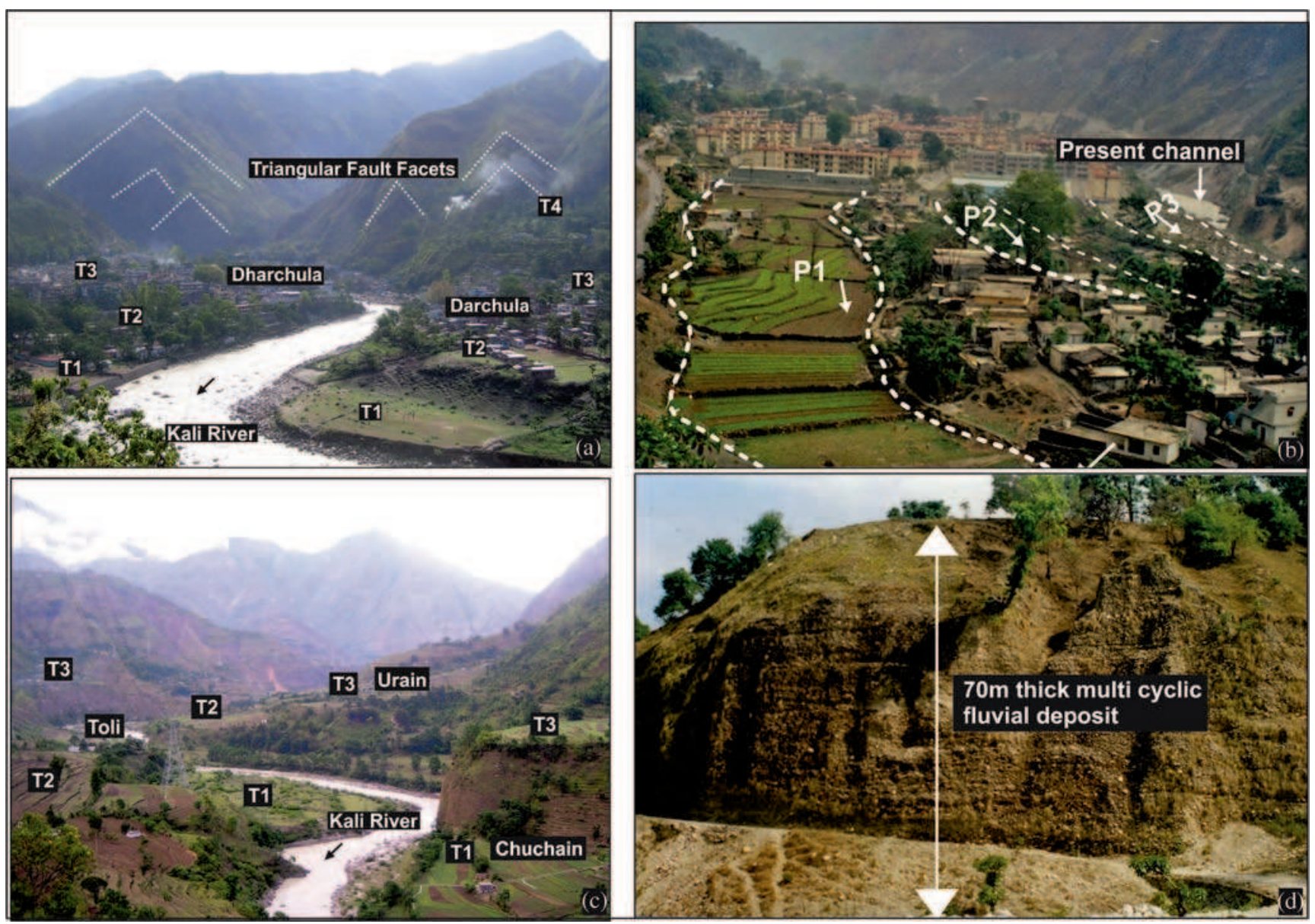

Figure 3. (a) Terrace deposition in Dharchula (India) and Darchula (Nepal) side; (b) series of three abundant paleochannel; (c) terraces along Kali river valley at Toli and Urain villages; and (d) 70-m thick multicyclic fluvial deposit in Gurgi Gad.

of $35 \mathrm{~m}$ from T3 surface, while at Gathibaggar $\mathrm{T} 1$ surface occurs at $3 \mathrm{~m}$ height from the present river level, and T2, T3 and T4 occur at a height of 10,12 and $55 \mathrm{~m}$ respectively from each other. The Gathibaggar block indicates upliftment with respect to the Dantu block. The presence of triangular fault facets on the left bank suggests that the right block has been uplifted due to activity along NE-SW trending Phultari-Nigalpani fault which extends from Phultari-Nigalpani to KalikaGathibaggar observed by authors near PhultariNigalpani and near Kalika Gathibaggar. This fault has caused upliftment of Phultari-Nigalpani block as evidenced from presence of three parallel abandoned channels at Nigalpani. The paleochannel $\left(\mathrm{P}_{3}, \mathrm{P}_{2}\right.$, and $\left.\mathrm{P}_{1}\right)$ is $600 \mathrm{~m}$ long, and $60,50,40 \mathrm{~m}$ wide respectively, and the paleochannel $\left(\mathrm{P}_{1}\right)$ is $90 \mathrm{~m}$ away from the present channel (figure $3 \mathrm{~b}$ ). The present course of Kali river valley is steep and narrow and at this place flows towards the left side of the abandoned channels. In Urain village (Nepal side) and Toli village (Indian side), three distinct level of terraces are observed, with the Toli village showing upliftment of $5 \mathrm{~m}$ (figure $3 \mathrm{c}$ ).
The tilting of Quaternary deposits is also clear along the valley near Gathibaggar. The Quaternary deposits comprise of fine sand (80-cm thick) and gravely sand (1.70-m thick) which shows tilting of bedding. The gravels comprise of approximately $60 \%$ of quartzite, $15 \%$ gneiss and $5 \%$ carbonate clasts. The matrix is gravely sand being largely framework supported. The beds dip 30-40 towards $\mathrm{N} 60^{\circ}$, indicating activity along PhultariNigalpani Fault.

A small tributary of the river Kali, joining it from Indian side near the village Titari, known as Gurji Gad, has deeply entrenched 70-m thick Quaternary sedimentary fill comprising several multicyclic fining upward sequences. It is pebble supported and comprises very well rounded clasts. The Gurji Gad is a misfit river as it has a very wide valley with very low water in it. The palaeocurrent direction measured from imbricated pebbles on both the banks of Gurji Gad is N270 . This direction is reverse to direction in which Gurji flows. This indicates that the Kali river was earlier flowing westerly in the area and presently flows in southerly direction. Since huge Quaternary 
deposits were deposited by the Kali river, subsequently the Gurji side was uplifted and forced the Kali to change its course. The upliftment accelerated the rate of entrenching of the Gurji Gad. Thus, the thick fluvial deposits of more than $70 \mathrm{~m}$ (figure 3d) are subsequently entrenched by Gurji Gad. Enormous debris mainly produced by the erosion of loose sedimentary fill is collapsing by toe cutting of Gurji Gad.

The main tributay of Kali river is Dhauliganga (east) which generally follows southeasterly direction and joins the Kali river at Tawaghat north of Dharchula (figure 2). In Dhauliganga river valley, from Tawaghat to Chirkila many ancient and recently active landslides are observed. Thick landslide deposits were seen from Khela village to Chirkila. Bali et al. (2002), also noticed several landslides within a short distance. A great waterfall of $280 \mathrm{~m}$ (figure 4a) is seen on the left bank of Dhauliganga and there are number of seasonal and perennial waterfalls along the valley. Potholes are one of the most spectacular geomorphic features seen in the valley. The potholes occur at different elevation $(40-50 \mathrm{~m})$ from the present river level (figure 4b), pothole indicating active channel incision into bed rocks (Springer et al. 2006). The presence of pothole at a height of $40-50 \mathrm{~m}$ from the present river level indicates high incision rate. This may be due to activity along $\mathrm{N}-\mathrm{S}$ trending Dhauliganga fault. Apart from the regular microseismic events (magnitude 2-4), this region has been frequently rocked by earthquakes of magnitude between 5 and 6 (Valdiya 1986; Paul et al. 2010). According to Gupta and Agarwal (1994), a number of smaller faults run along and across the river. The Dhauliganga river runs along a northsouth trending Dhauliganga Fault. The nature of seismicity and movements along faults and thrust are one of the major triggering parameters of landslide in this region.

The northeastern part of Kumaun near Dharchula and its surroundings along the Kali river valley have been affected by several natural hazards like landslides, mass movements, flash floods, cloud-bursts and earthquakes. Slopes in the region were formed by combining the effect of geomorphic, tectonic and climatic process and the landslides frequently occurring during the monsoon. The highly deformed, fractured and shattered rocks of Great Himalaya and the proximity of active thrusts and fault zones might have played a major role in rock falls and landslides in the region. During field investigation, authors noticed thick ancient landslide deposits along the valleys, some being active. The frequent occurrences of micro-seismic events in the region suggest that the valley is under stress and tectonic adjustments are going on in the region.

\subsection{Geomorphic indicators of neotectonic activity along Ramganga (east) river valley}

In the Ramganga (east) valley from Birthi to Muwani, various geomorphic features are observed and shown in figures 5 and $6(\mathrm{a}-\mathrm{d})$. The tributary, Jakula Gad that joins the Ramganga at Tejam shows terrace depositions along its banks. During
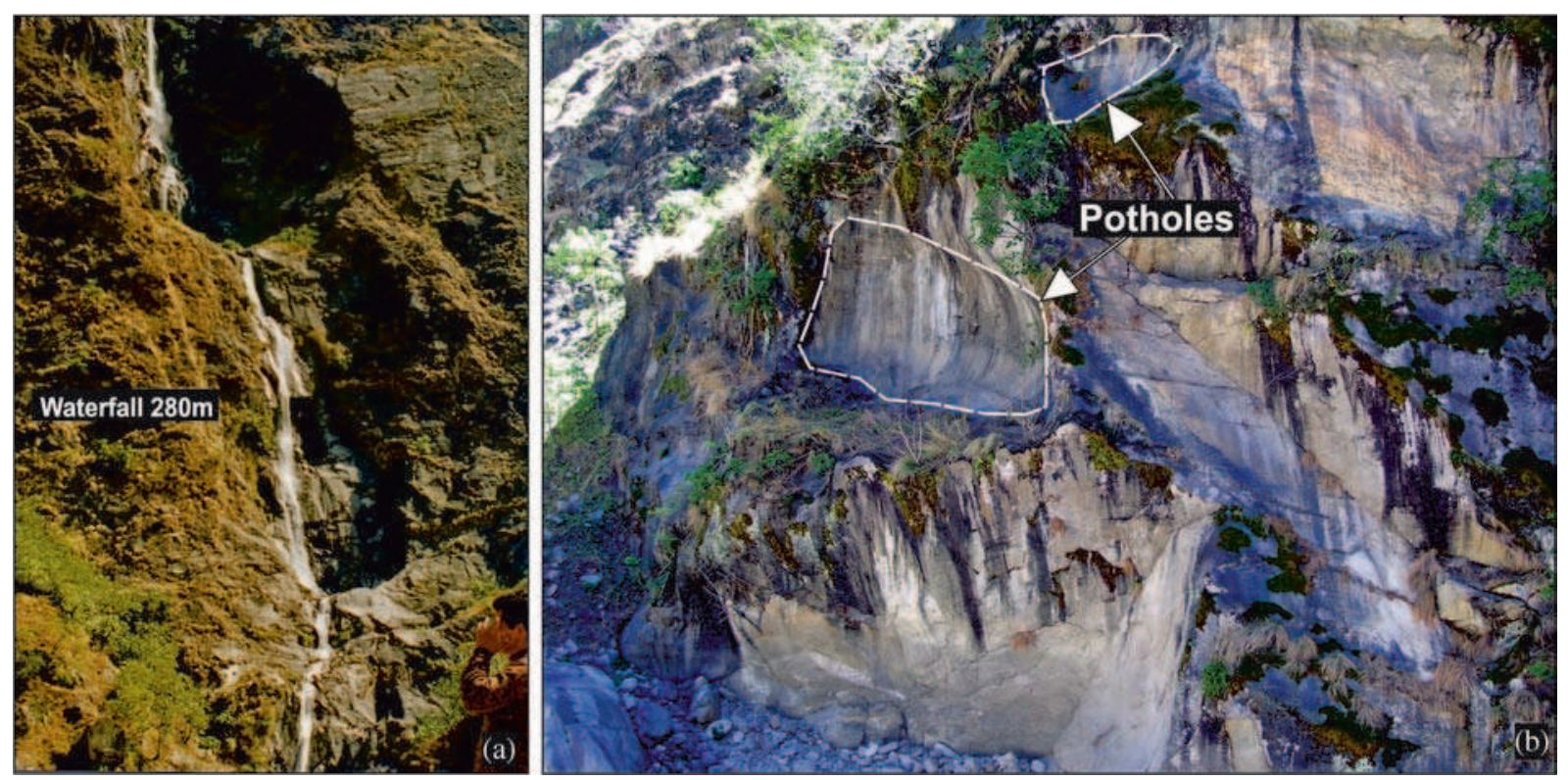

Figure 4. (a) 280-m waterfall at Dhauliganga river valley near Chirkila and (b) 40-50 m high potholes from present Dhauliganga river channel. 


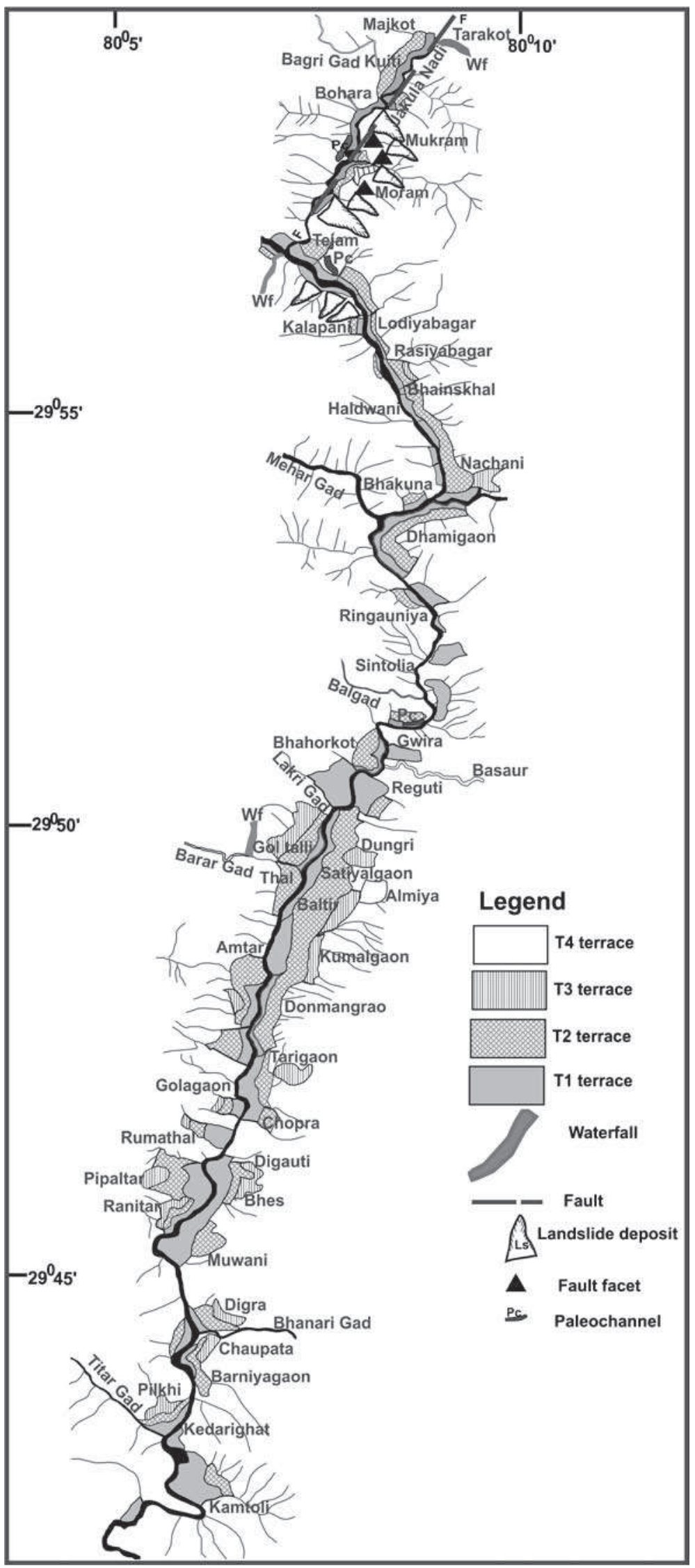

Figure 5. Various geomorphic features along Ramganga (east) river valley. 

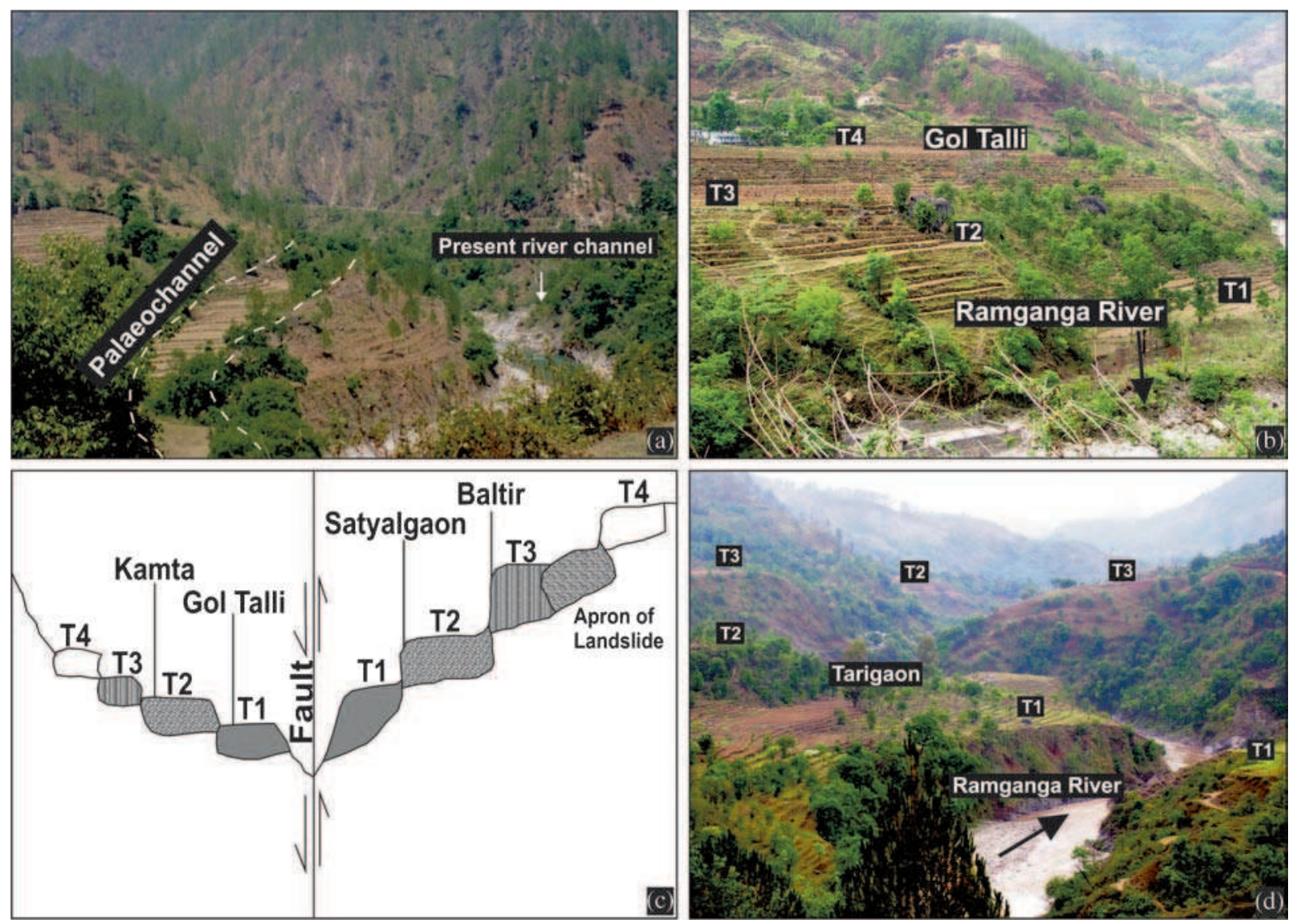

Figure 6. (a) Palaeochannel in Ramganga east river; (b) deposition of terraces at Gol Talli village near Thal, Ramganga east river valley; (c) upliftment along the fault; and (d) various levels of terraces at Tarigaon village, Ramganga east valley.

investigation differentially uplifted terraces are observed in the valley. The left bank of the river Jakula is characterized by the presence of series of huge landslides, triangular fault facets, waterfall of $80 \mathrm{~m}$ (Birthi waterfall), and a paleochannel at the right bank that is $100 \mathrm{~m}$ eastward from the present river level is also observed. This could be related to the activity along NNE-SSW trending Jakula Fault which has caused upliftment of right block.

At Tejam (confluence of Ramganga and Jakula), a $600 \mathrm{~m}$ long and $40 \mathrm{~m}$ wide paleochannel lies $20 \mathrm{~m}$ away and $25 \mathrm{~m}$ above the present river level (figure 6a). The right bank of Ramganga river shows poor development of terraces. Moreover, the laterally extensive and wide terraces are seen on the left bank. This could be due to upliftment of left bank (upthrown block). So terraces developed successively preserved in the left bank and on the right bank the developed terraces were eroded as it is on downthrown side.

At Thal, four levels of unpaired terraces are exposed on both sides of the river with significant altitudinal variation indicating uplift of the left bank (figure 6b, c). Various levels of terrace deposits are also observed in Tarigaon village (figure 6d). In Pipaltar, the left bank of river
Ramganga is uplifted $15 \mathrm{~m}$ compared to the right bank block. All this could be related to the activity along Ramganga Fault which is extended from Muwani upto Tejam. Earlier, Pant (1985) mapped this fault along Ramganga valley in Muwani where it displaces Berinag Thrust to the order of $1.5 \mathrm{~km}$. This transverse fault has dextrally displaced the various lithotectonic boundaries. The existence of the fault is testified by almost straight course of the Ramganga river in this region, presence of paleochannels, rare preservation of terraces along downthrown side and the extreme crushing, pulverization, silicification, variation of dip and strike, extensive landslide fans, and almost vertical landslide scars along the fault line are other evidences, that indicate activeness of the fault.

\subsection{Geomorphic indicators of neotectonic activity along Gori Ganga river}

Geomorphic signatures of neotectonics were also investigated in the Gori Ganga valley from Jauljibi to Madkot. Figure 7 shows the distribution of these geomorphic features along the valley. The most common three levels of fluvial terraces are 


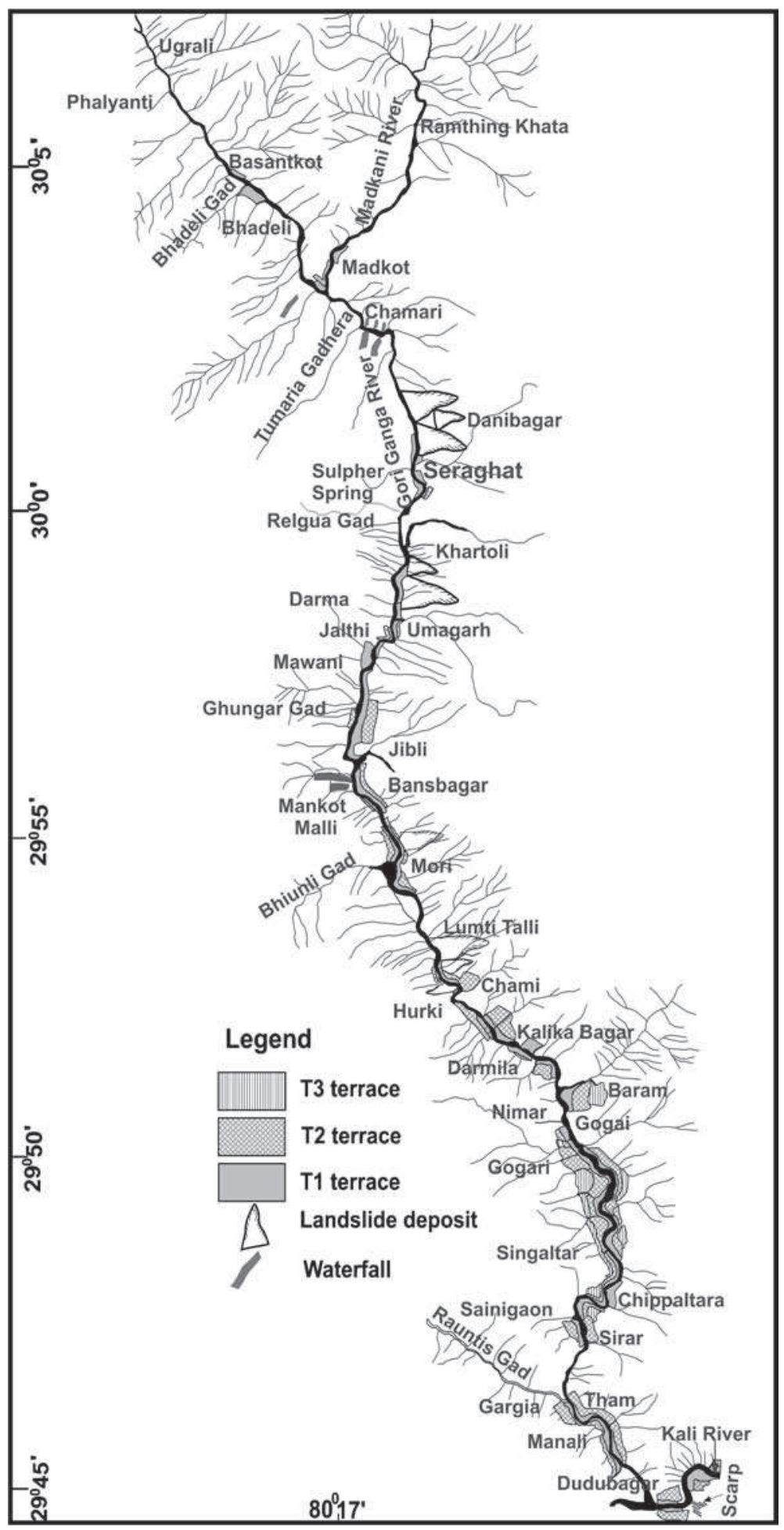

Figure 7. Various geomorphic features along Gori Ganga river valley.

restricted to the valleys upstream of active faults and thrusts manifest pulses of episodic upliftment. However, some faults and thrusts are locally associated with more than three terrace levels. In some places, six levels have been reported indicating that some thrusts have recorded a few pulses of uplift (Valdiya 1993, 2001; Luirei et al. 2006). At Jauljibi, two levels of terraces are exposed on right bank and steep scarp on the left bank of Gori Ganga. T1 occurs at $12 \mathrm{~m}$ from the present river level and $\mathrm{T} 2$ exposed between 20 and $25 \mathrm{~m}$ from the T1 surface.

Near Garjia two levels of terrace are developed on both sides of the river. Here T1 is $5 \mathrm{~m}$ from the present level of the river and T2 is $10 \mathrm{~m}$ from the 


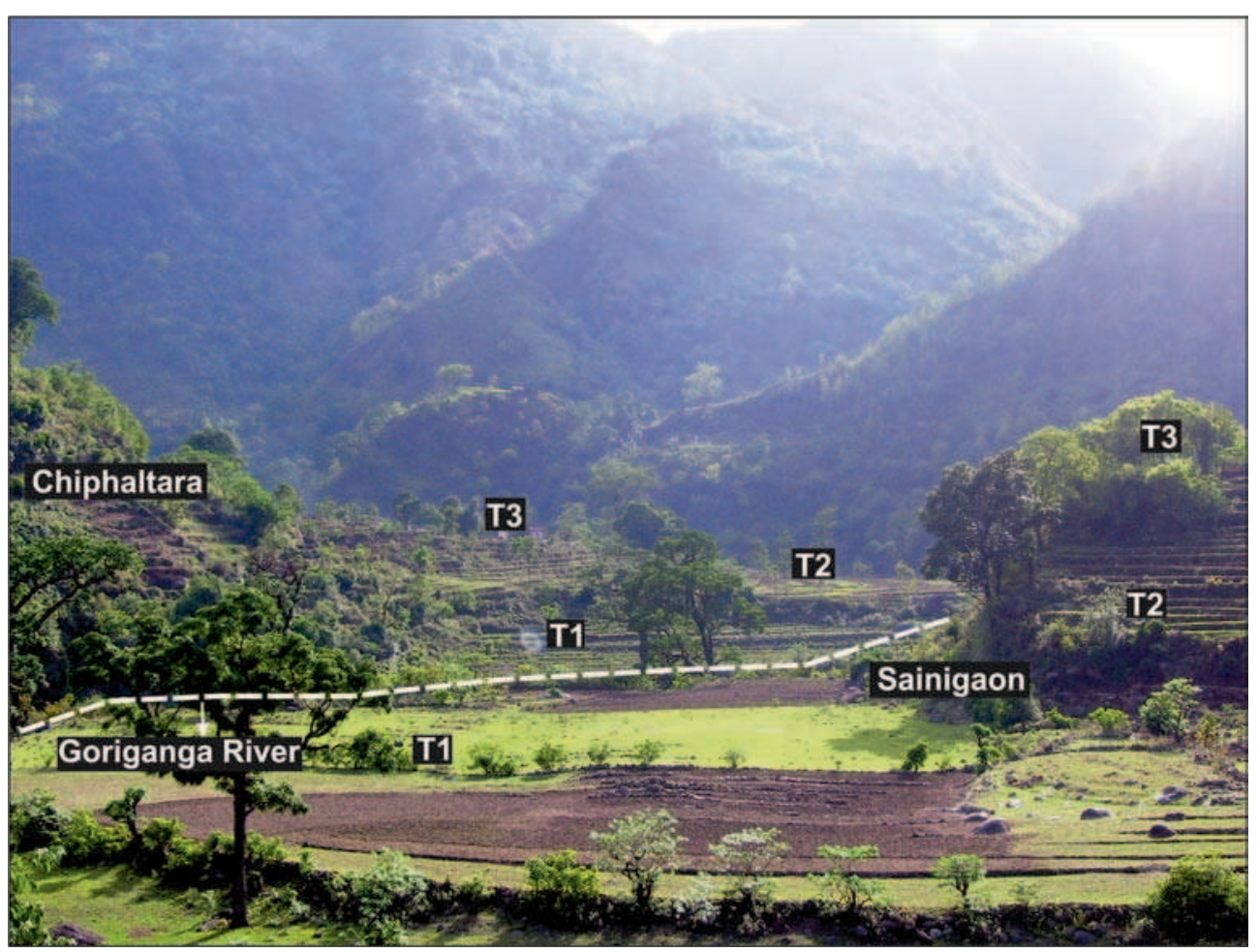

Figure 8. Terrace deposition at Chiphaltara and Sainigaon, Gori Ganga river valley.

T1 surface; a $46 \mathrm{~m}$ high waterfall is also observed. At Sainigaon, on the right bank of the Gori Ganga, three distinct levels of terraces are seen. T1 being $3 \mathrm{~m}$ from the present river level, T2 is $25 \mathrm{~m}$ from $\mathrm{T} 1$ and T3 occurs at $20 \mathrm{~m}$ from the T2 surface, while on the left bank at Chiphaltara T1 occurs at $5 \mathrm{~m}$ height from the present river level and $\mathrm{T} 2$ being $\mathrm{m}$ from the $\mathrm{T} 1$ surface and T3 occurs at $12 \mathrm{~m}$ from T2 surface (figure 8). The village, Singaltar is situated on right bank of the river. Here three distinct levels of terraces are exposed. T1 occurs at $8 \mathrm{~m}$ from the present river level, T2 being $8 \mathrm{~m}$ from the T1 surface and T3 being $15 \mathrm{~m}$ high from the T2 surface, while in the left bank $\mathrm{T} 1$ occurs at a height of $5 \mathrm{~m}$ from the present river level, T2 being $15 \mathrm{~m}$ from the $\mathrm{T} 1$ and $\mathrm{T} 3$ is $20 \mathrm{~m}$ from the T2 surface. The terraces at right bank occur at higher position, suggesting movement along NW-SE trending Baram Fault which passes through Toli and Baram villages. An abandoned channel is seen on the left bank of Gori Ganga. This channel is located in Toli Singaltar village. It is approximately $250 \mathrm{~m}$ long, $25 \mathrm{~m}$ wide, $12 \mathrm{~m}$ height and occurs at $50 \mathrm{~m}$ height from the present river level, indicating neotectonic activity along Baram Fault. The existence of this Fault is testified by the truncation of the Mandhali or Deoban rocks of the Tejam Group and the granitic gneiss of the Munsiari lithological units, slickensides near Chhipaltara, landslides near Toli and Balmara and the presence of the mylonites throughout the fault zone, etc.
From Baram to Umagarh, two levels of terraces are seen on both sides of Gori river (figure 7) and active landslides are also noticed in some places. Between Umagarh to Madkot the river flows through a deep gorge with vertical scarp on both sides of the river. The valley becomes wide just before confluence of Gori Ganga and its tributary (Madkani). Near Madkot two surfaces of terraces are seen. T1 occurs at an elevation of $8 \mathrm{~m}$ from the present river level and T2 is $6 \mathrm{~m}$ from the T1 surface. There are number of seasonal and permanent waterfalls between Jauljibi to Madkot on both the sides of the Gori Ganga river. At Sirtola there is $50 \mathrm{~m}$ high waterfall at left bank of Gori Ganga. At Chamrari, two waterfalls on right bank and three along the left bank are seen having a fall of $75 \mathrm{~m}$ at Sungariya Gadhera close to Madkot. The Madkot waterfall is located at a height of $50 \mathrm{~m}$ on the right bank of the Gori Ganga river. The water of these falls are rich in sulphur.

The hot water springs are also noticed near Madkot. Springs are often found along the fault zone because the crushed rocks associated with faulting can be either an effective barrier to, or conduit of, groundwater, forcing it to the surface (Keller and Pinter 1996). On the basis of the above observation, a NNW-SSE trending fault, named as Madkot Fault follows the general course of the river Gori from Polu to about $3 \mathrm{~km}$ SSE of Madhkot. The occurrence of hot springs along the Madkot Fault indicates its deep-seated nature. It acts as oblique 
ramps, i.e., juxtaposing the Vaikrita Thrust in the north and the Chhiplakot Fault in the south (Paul 1998).

\section{Analysis of seismic data}

The network recorded large number of lower magnitude earthquakes in the Lesser Kumaun Himalaya region. The epicentral map of the region includes EHB events shown in figure 9. The earthquake events are extracted from the continuous seismic data. The events include local, regional and teleseismic. Subsequently, detailed analysis was carried out for local events to evaluate the localized seismicity. The local events are further analyzed to study (i) the hypocentral parameters, (ii) source parameters, (iii) seismicity of the area which delineates some energy releasing sectors in the region, and (iv) seismic hazard estimation of the region. In the present investigation, 164 events from the year 1999-2008 are considered whose epicenters fall in the study area (figure 9).

The magnitude $\mathrm{M}_{\mathrm{L}}$ of the events lie between 1.0 and 5.1 and stress drop values range between 0.01 bar for an earthquake of $\mathrm{M}_{\mathrm{L}}=1.7$ and 59.7 bar for an earthquake of $\mathrm{M}_{\mathrm{L}}=3.0$. The stress drop values for 36 earthquake events were found to be more than 10 bars, with a maximum of 59.7 bars.
For 74 earthquake events, the stress drop was computed between 1 and 10 bar, and for 44 earthquake events the stress drop was estimated to be very low, i.e., $<1$ bar. The estimated seismic moment of the seismic events ranges from $2.19 \times 10^{11} \mathrm{Nm}$ to $4.39 \times 10^{15} \mathrm{Nm}$. The source radius values lie between 107 and $760 \mathrm{~m}$.

It is evident from figure 9 that most of the seismicity is clustered between Main Central Thrust (MCT) and Berinag Thrust (BT). Three seismic zones can be identified from figure 9. These are: (1) Between Main Central Thrust and Berinag Thrust, (2) North of Main Central Thrust near Nandadevi, and (3) Northeastern part of Kumaun and adjoining part of western Nepal along Kali valley. The present study shows that MCT is active at present as evident from the seismological data and morphotectonic investigations near MCT. Figure 9 indicates that, presently, most of the seismic activity is taking place at south of MCT and its subsidiary thrusts. On the basis of the epicentral distribution, a sector of energy release (figure 9 ) is identified that is almost parallel to the trend of Himalayan Thrust. The cluster of events is concentrated between the BT and MCT (see figure 9), also indicating that this part is more seismically active as compared to the remaining Kumaun Lesser Himalaya region. Earthquakes of magnitude 3 or less are frequently occurring in this region. The frequently occurring

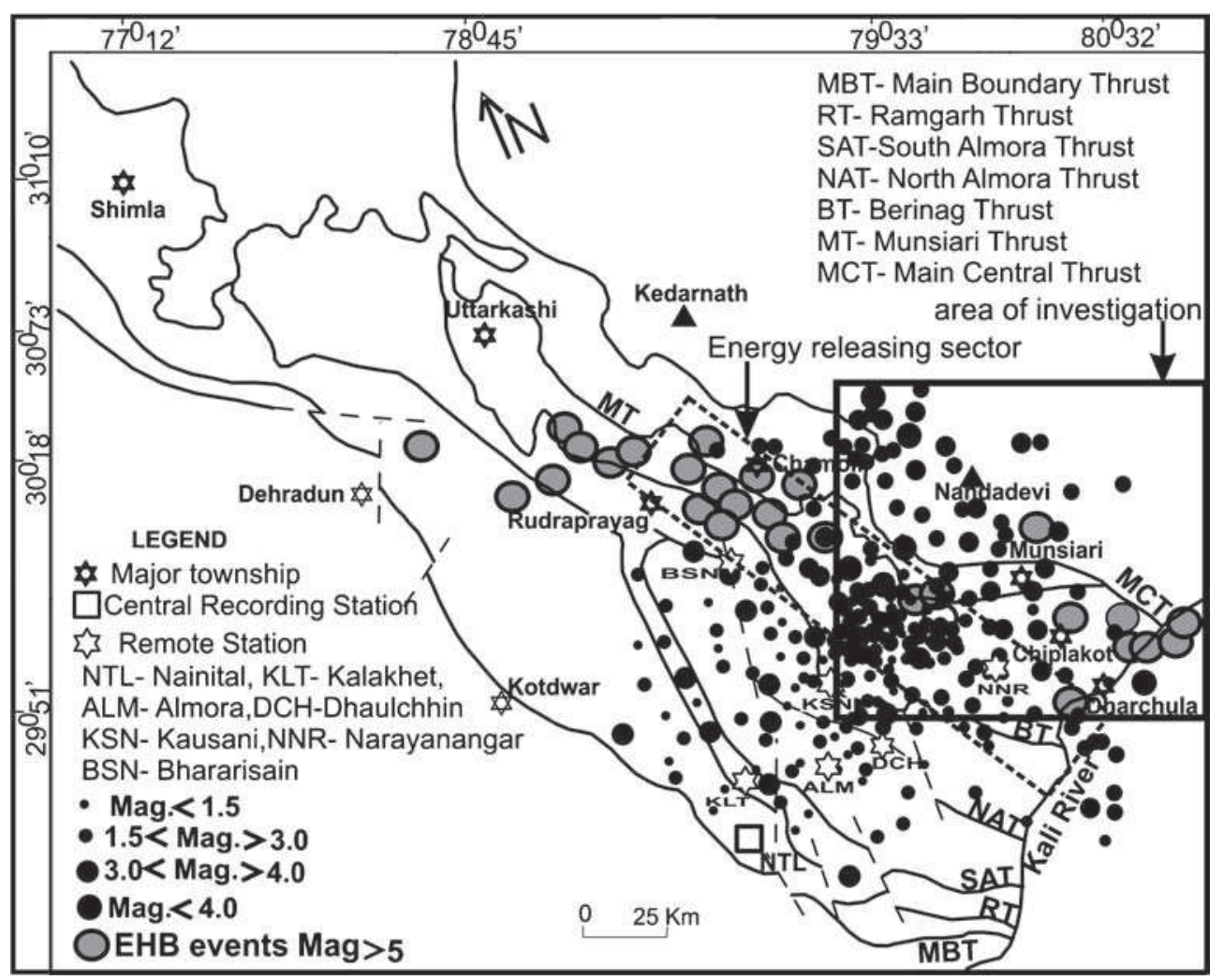

Figure 9. Epicentral distribution map of the study area as recorded by the network along with EHB events, seismicity is relatively high just south of MCT, dotted transect showing energy releasing sector. 
earthquakes are a result of strain accumulation. These micro-earthquakes with shallow focal depths and low stress drop can be explained by partial stress drop model. The relatively low stress drops at shallow focal depths indicate that the rock which forms the upper part of the crust in this region has low strength of accumulation of strain and undergoes brittle fracture and adjustment.

The focal depth analysis of the events was carried out with the error bar $<2.5 \mathrm{~km}$ and was recorded by at least four stations. Out of 164 events, 83 events were found suitable for focal depth analysis. The error bars of the remaining events were slightly higher than $2.5 \mathrm{~km}$ and so they have not been considered. The earthquakes occurring in the region are shallow in nature (figure 10), and lies mostly between 10 and $20 \mathrm{~km}$. Earlier, $\mathrm{Ni}$ and Barazangi (1984), Pant and Paul (2007), Pathak et al. (2013), reported occurrence of shallow focus earthquakes in Himalaya region and also observed that their hypocentral depth increases.

In the present work, it has been found that the peak ground acceleration (PGA) values of the events vary from $1.8 \times 10^{-6} \mathrm{~m} / \mathrm{s}^{2}(\mathrm{E})$ for the earthquake of magnitude 2.6 to $2.0 \times 10^{-3} \mathrm{~m} / \mathrm{s}^{2}(\mathrm{E})$ for earthquake of magnitude 4.8. The values of peak ground velocity $(\mathrm{PGV})$ varies from $2.2 \times 10^{-6} \mathrm{~m} / \mathrm{s}$ to $16.6 \times 10^{-2} \mathrm{~m} / \mathrm{s}$. The PGA and PGV indicate the maximum values of acceleration and velocity during an earthquake and show two asperities

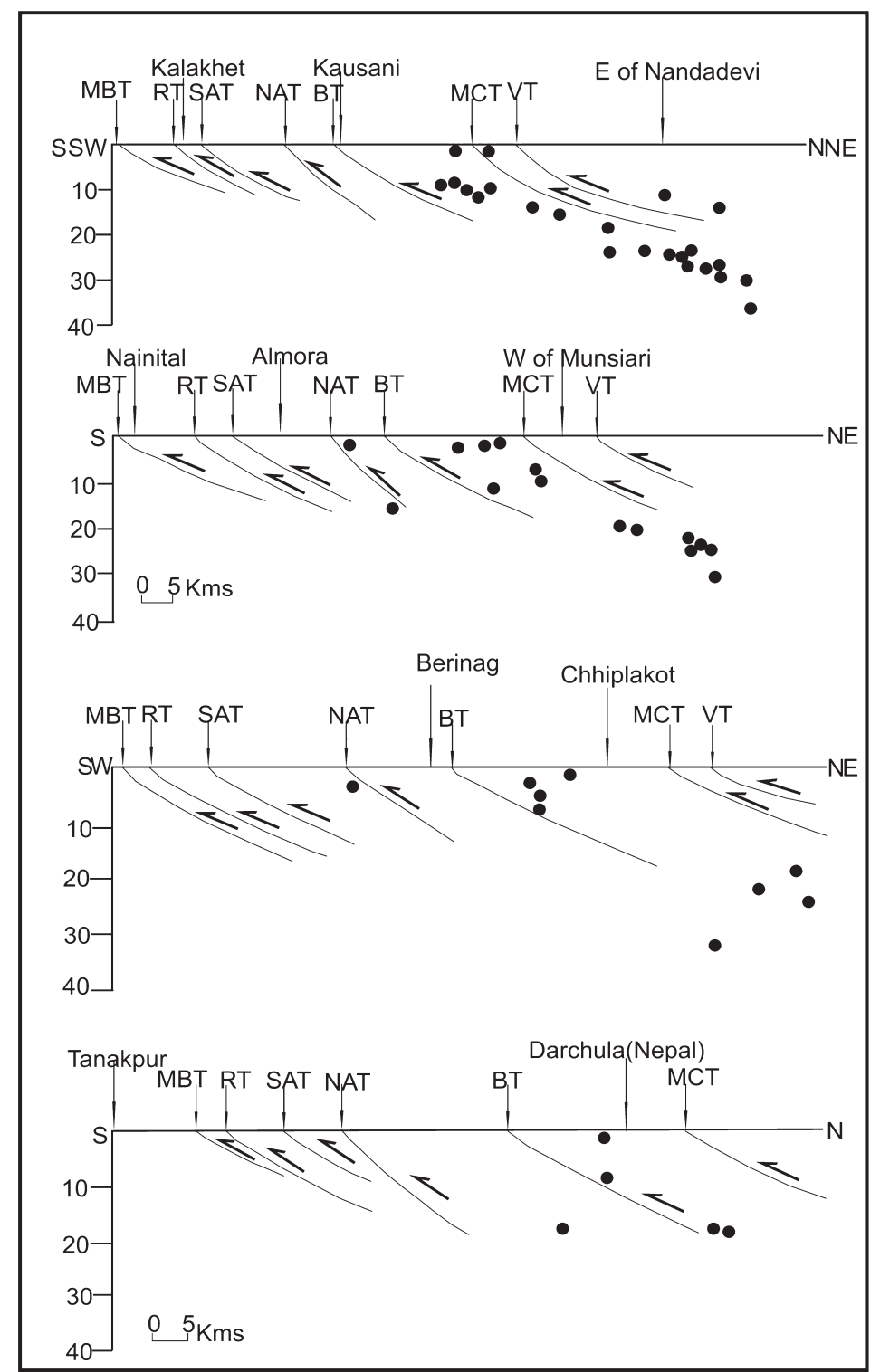

MBT- Main Boundary Thrust, RT- Ramgarh Thrust, SAT- South Almora Thrust NAT- North Almora Thrust, BT- Berinag Thrust, MCT- Main Central Thrust. VT- Vakrita Thrust

Figure 10. Depth distributions of the earthquake events and their relation with the thrust/fault of the area. 
in the region, one along NW-SE direction almost parallel to the thrusts of regional extent, viz. Main Central Thrust, Munsiari Thrust, Berinag Thrust, North Almora Thrust and other is orthogonally along $\mathrm{N}-\mathrm{S} / \mathrm{NNW}-\mathrm{SSE}$ directions. These areas are more prone to earthquakes and are thus relatively more seismically hazardous. The PGV are high in Dharchula and environ and adjoining part of western Nepal, Nandadevi and nearby places, Bhararisain and Rudraprayag areas.

\section{Conclusions}

Detailed field investigation along the major river valleys of the northeastern Kumaun (Kali, Dhauliganga, Gori Ganga and Ramganga east) shows that the northeastern part of the Kumaun Himalaya is very active as indicated by several geomorphic features like abandoned channels, uplifted terraces, tilted Quaternary deposits, waterfalls, uplifted potholes, fluvial terraces, triangular facets and hot water and sulpher springs, etc. In the absence of OSL/TL dates of the terrace material, it is not possible to provide the exact chronology and rates of uplift along the faults. However, an attempt is being made to date the terrace material and provide the chronology of events.

As these features are found near the major discontinuity Main Central Thrust (MCT), they suggest that the MCT and transverse faults/thrust are quite active. The seismic pattern of the events of this part shows two regions along which most of the strain energy is being released. These regions trend NW-SE direction almost parallel to the Himalayan trend or regional thrusts, viz., Main Central Thrust/Berinag Thrust/North Almora Thrust and orthogonally along N-S/NNW-SSE directions. The seismic pattern study of the events which fall in the area shows that most of the events are clustered between Main Central Thrust (MCT) and Berinag Thrust (BT). This region in general shows three transects along which seismicity is very high in the study area. These are:

(1) Between Main Central Thrust and Berinag Thrust.

(2) North of Main Central Thrust near Nandadevi.

(3) Northeastern part of Kumaun and adjoining part of western Nepal along Kali valley.

The higher seismicity of the region and their association with seismic pattern and epicentral distribution suggest that some of the faults of the area are neotectonically active. The present study shows that intracrustal boundary thrusts including MCT are active at present as evident from the seismological data and morphotectonic investigation. The shallow seismicity and low stress drop suggest that the crust of the region is not able to withstand the strains. The shallow seismicity and the surface deformational features in a different river valley indicate that the region is undergoing neotectonic rejuvenation. In absence of chronology of the deposits, it is difficult to relate them with extant seismicity. The Uttarakhand Himalaya is seismically very active and is drained by many perennial rivers with numerous tributaries. A large number of multipurpose river valley schemes have been conceived for the region and many of them are under execution or in advanced stage of design. So, detailed seismicity information would be very important in planning seismic risk mitigation measures for these projects. The data in the light of upcoming hydropower and developmental projects in the region would be significant to the various agencies.

\section{Acknowledgements}

The authors express their sincere gratitude to the Ministry of Earth Sciences, New Delhi for sponsoring the SNKH project. They are thankful to the Head, Centre of Advanced Study in Geology, Kumaun University for providing the infrastructural facility. Dr B K Bansal, Head Geosciences, New Delhi, Dr Ajay Paul, WIHG, Dehradun and Prof. P K Goswami, Kumaun University, Nainital are acknowledged for fruitful discussion and suggestions. The three anonymous reviewers are also thanked for suggestions which substantially improved the manuscript.

\section{References}

Avouac J P and Tapponnier P 1993 Kinematic model of active deformation in Asia; Geophys. Res. Lett. 20 895-898.

Bali R, Ydhbir, Sharma A K and Ranhotra P S 2002 Landslide hazard micro-zonation of Tawaghat-Sobla area, Kumaun Himalaya; In: Aspects of Geology and Environment of Lesser Himalaya (eds) Pant C C and Sharma A K, Gyanodaya Prakashan, 475p.

Banerjee P and Bürgmann R 2002 Convergence across the northwest Himalaya from GPS measurements; Geophys. Res. Lett. 29 30-1-30-4.

Bhattacharya A R and Weber K 2004 Fabric development during shear deformation in the Main Central Thrust Zone, NW-Himalaya, India; Tectonophys. 387 23-46.

Bilham R, Larson K and Freymueller J 1997 GPS measurements of present day convergence across the Nepal Himalaya; Nature 386 61-64.

Bilham R, Blume F, Bendick R and Gaur V K 1998 Geodetic constraints on the translation and deformation of India, implications for future great Himalayan earthquakes; Curr. Sci. 74 213-229.

Brune J N 1970 Tectonic stress and spectra of seismic shear waves from earthquakes; J. Geophys. Res. 75 4997-5009. 
Bull W B 1991 Geomorphic Response to Climate Change; Oxford University Press, Oxford, 329p.

Bull W B and Knuepfer P L K 1987 Adjustment by the Charwell River, New Zealand, to uplift and climate changes; Geomorphology 1 15-32.

England P C and Molnar P 1997 Active deformation of Asia from kinematics to dynamics; Science 278 643-662.

Goswami P K and Pant C C 2007 Geomorphology and tectonics of Kota-Pawalgarh Duns, Central Kumaun SubHimalaya; Curr. Sci. 92(5) 685-690.

Goswami P K and Pant C C 2008 Morphotectonic evaluation of Bainu-Ramganga-Naurar tranverse valley, southern Kumaun Lesser Himalaya; Curr. Sci. 92(12) 1640-1645.

Gupta G K and Agarawal R K 1994 Geothermal studies on the Darma valley, thermal spring belt, Pithoragarh district, Uttar Pradesh; GSI Records 127(8) 240-242.

Keller A and Edward Pinter N 1996 Active tectonics: Earthquake, uplift and landscape; Prentice Hall, Upper Saddle River, New Jersey 07458, 338p.

Khattri K N and Tyagi A K 1983 Seismicity patterns in the Himalayan plate boundary and identification of the areas of high seismic potential; Tectonophys. 96 281-297.

Khattri K N, Chander R, Gaur V K, Sarkar I and Kumar S 1989 New seismological results on the tectonics of the Garhwal Himalaya; Proc. Indian Acad. Sci. (Earth Planet. Sci.) 98 91-109.

Larson K, Bürgmann R, Bilham R and Freymueller J T 1999 kinematics of the India-Eurasia collision zone from GPS measurements; J. Geophys. Res. 104 1077-1093.

Lee W H K and Lahr J C 1975 Hypo71 (revised): A computer program for determining hypocenter, magnitude and first motion pattern of local earthquakes; U.S. Geol. Surv. Open-File Rep. 75-311: 1-116.

Luirei K, Pant P D and Kothyari G C 2006 Geomorphic evidences of neotectonic movements in Dharchula area, northeast Kumaun: A perspective of the recent tectonic activity; J. Geol. Soc. India 67 92-100.

Maddy D, Bridgland D R and Green C P 2000 Crustal uplift in southen England: Evidences from the river terrace records; Geomorphology 33 167-181.

Nakata T 1975 On Quaternary tectonics around the Himalaya; Sci. Rep. Tohuko Univ. $7^{\text {th }}$ Ser. (Geogr). 25 111-118.

Nakata T 1989 Active faults of the Himalaya of India and Nepal; Geol. Soc. Am. Spec. Paper 232 243-264.

$\mathrm{Ni} J$ and Barazangi M 1984 Seismotectonics of the Himalayan collision zone: Geometry of the underthrusting Indian Plate beneath the Himalaya; J. Geophys. Res. 89 1147-1163.

Pant C C 1985 Stromatolites from Middle-Riphean Gangolihat Dolomites (Deoban), Berinag-Gangolihat area, Pithoragarh District, Kumaun Lesser Himalaya; J. Geol. Soc. India 26 1-9.

Pant C C and Paul A 2007 Recent trends in seismicity of Uttaranchal; J. Geol. Soc. India 70 619-626.

Parkash B, Rathor R S, Pati P, Jakhmola R P and Singh S 2011 Convergence rates along the Himalayan Frontal
Thrust inferred from terraces at Chandidevi Temple Hill, Hardwar, northwestern Himalaya; Curr. Sci. 100(9) 1426-1432.

Pathak V, Pant C C and Darmwal G S 2013 Geomorphological and seismological investigations in a part of western Kumaun Himalaya, Uttarakhand, India; Geomorphology 193 81-90.

Paul S K 1985 Structural and petrological studies of Munsiari Dharchula area, Great Himalaya in Kumaun; Unpubl. Ph.D. thesis, Kumaun University, Nainital.

Paul S K 1998 Geology and tectonics of the central crystallines of northeastern Kumaun Himalaya, India; $J$. Nepal Geol. Soc. 18 151-167.

Paul A, Bhakuni S S, Pant C C, Darmwal G S and Pathak V 2010 Microseismicity in central part of inner Kumaun Lesser Himalaya: Implications to active seismotectonics; Him. Geol. 31(2) 105-115.

Sah M P and Virdi N S 1997 Geomorphic signatures of neotectonic activity along the Sumdo Fault, Spiti valley, District Kinnaur, Himanchal Pradesh; Him. Geol. 18 $81-92$.

Senthil K, Wesnousky S G, Rockwell T K, Ragona D, Thakur V C and Seitz G G 2001 Earthquake recurrence and rupture dynamics of Himalayan Frontal Thrust, India; Science 294(5550) 2328-2331, doi: 10.1126/ science.1066195.

Sharma M L and Wason H R 1994 Occurrence of low stress drop earthquake in the Garhwal Himalaya region; Phys. Earth Planet. Int. 85 265-272.

Springer G S, Tooth S, Ellen E and Wohl E E 2006 Theoretical modeling of stream potholes based open empirical observations from the Orange River, Republic of South Africa; Geomorphology 82 160-176.

Sridevi J 2004 Estimates of plate velocity and crustal deformation in the Indian subcontinent using GPS geodesy; Curr. Sci. 86 1443-1448.

Thakur V C 2004 Active tectonics of Himalayan frontal thrust and seismic hazard to Ganga Plain; Curr. Sci. 86(11) 1554-1560.

Valdiya K S 1979 An outline of the structural set-up of Kumaun Himalaya; J. Geol. Soc. India 20 145-157.

Valdiya K S 1980 Geology of Kumaun Lesser Himalaya; Wadia Institute of Himalayan Geology, Dehradun, U.P., 291p.

Valdiya K S 1986 Neotectonic activities in the Himalayan Belt; In: Proc. of International Symposium on Neotectonics in South Asia; Survey of India, Dehradun, pp. $241-267$.

Valdiya K S 1993 Uplift and geomorphic rejuvenation of the Himalaya in the Quaternary period; Curr. Sci. 64 873-885.

Valdiya K S 2001 Reactivation of terrane-defining boundary thrusts in central sector of the Himalaya; Curr. Sci. 81(11) 1418-1431.

Wesnousky S G, Kumar S, Mohindra R and Thakur V C 1999 Uplift and the convergence along the Himalayan Frontal Thrust; Tectonics 18(6) 967-976. 